\title{
Features of Capitalism and the Restructuring of Ruling Classes in China
}

TORSTEIN HJELLUM

\section{Abstract}

The questions that will be discussed in this paper are the following: Is it possible to identify capitalist classes, or a Chinese bourgeoisie (as a faceted mixture of diverse capitalist groups or classes) at the end of the 1990s? Are capitalist classes becoming an integral part of a "ruling class' or a collective body of 'ruling classes'? Is 'bureaucratic capitalism' a proper term of Chinese capitalism?

This is an ambitious task: It involves complex and contested concepts, that of 'class', 'capitalist class' and 'ruling class' and it tries to relate them to a very complicated historical process actually taking place in the largest country in the world. However, the questions involved are, or should be, of the greatest interest to the Chinese people and social scientists. In the paper I try to summarize some literature on the subject and to interpret some empirical findings from a class-theoretical perspective in the hope of stimulating further studies and debates.

The author argues that the actual modernization of the Chinese economy is producing new economic elites which will constitute a Chinese 'bourgeoisie' among which state and party cadres are in the lead. The specific state-led capitalism should be properly labelled 'bureaucratic capitalism'. 
Torstein Hjellum

\section{A Concept of 'Ruling Class' and 'Capitalist Class'}

A society's ruling class or its collective body of ruling classes may be defined in the intersection of three hierarchies: a hierarchy of wealth (in the economy), a hierarchy of justification or legitimation (prestige and honour based on prevailing myths and ideologies) and the hierarchy of power (in the polity). The role and importance of these hierarchies may differ greatly from one society to another and also within a society during its history.

A crucial differentiation of people in a society is determined according to their power to appropriate commodities and ownership or control of means of production and real estates. According to the kind of power, or power-base they possess, groups of people find their place in a societal class system. The conditions of appropriation in a society define and differentiate the class system of societies.

In the tradition of Smith, Ricardo and Marx a capitalist class is defined by their members' interest in surplus-value production: the exploitation of labour in commodity production based on ownership or control over the means of production. We can thus define a class of people as a real or 'objective' position in the societal system of production, regardless of the class members' own awareness or consciousness about their position. If the inequalities between groups are understood as based on relations of production, interest conflicts will take the form of 'class struggles'. Class is also a 'subjective' phenomenon, perceived by individuals who 'objectively' belong to the class. Classes begin to exist 'für sich'. A class may be identified in its totality of objectivities and subjectivities. According to this definition, not all social contradictions are class contradictions, as the Maoists of the Cultural Revolution perceived it.

We should have in mind that there is always, even in the most developed capitalist societies, a great variation of forms of ownership and control over the means of production, that forms are changing from one capitalist society to another, and over time. The crucial point in relation to class is the exercise of power to decide on production and the distribution of the value 
of production, which includes the possibility of private expropriation in one form or another.

As the conditions of appropriation change, the former economic privileged classes are going to be restructured or vanish. 'Nouveaux riches' will join them or replace them. The suggestion here is that as the reform process is going on in China, the materially privileged classes will increasingly share characteristics with their counterparts in Western capitalism. ${ }^{1}$ However, a Chinese 'bourgeoisie' should have its own characteristics, dependent on the specificities of historical traditions in China, ${ }^{2}$ the character of the transition of the former regime and the actual world-historical context. The world-historical context within which a Chinese 'bourgeoisie' will develop, has two main aspects: a continued globalization of marked capitalism and a world political regime where the United States plays a dominant role as the only superpower.

It is not least important to underline the variation of forms when we are analysing a society like China. Since the end of the 1970s China has been radically reformed based on a fundamental shift of paradigms of development. Especially in such a society we may expect a great variety of forms of ownership and power, new kinds of mixtures of old and new.

\section{'Bureaucratic Capitalism'?}

The ideal type of liberal capitalism is associated with a society where private wealth is the main resource of the ruling elites, with the state subordinated to the economy and with the rights of the individuals as the legitimating principle.

In China, capitalism in its different forms and stages has usually been subordinated to the polity. During imperial rule, the state bureaucrats controlled merchant capitalism-the scholar-officials and the merchants formed two hostile but interdependent classes. The system may be characterized by the term 'bureaucratic capitalism' referring to the use of political power and official influence for private pecuniary gain through capitalist or quasi-capitalist methods of economic activity. "The 
golden age of the Chinese bourgeoisie', in the absence of a strong state at the beginning of the 20th century, was indeed brief. The Nationalist government from 1927-28 inaugurated a two-decade reign that is perhaps the archetyal case of bureaucratic capitalism in modern world history. The communist victory of 1949 ended the Goumindang system of bureaucratic capitalism.

The current Chinese political regime in transition has been given various labels: 'post-totalitarian', ' 'bureaucratic capitalism', 4 'nomenclature capitalism', 'free-market communism', 'capitalism with a Stalinist face', etc. In spite of differing labels, there seem to be a consensus that an industrial revolution is taking place and that this economic revolution has the character of capitalism. Maurice Meisner identifies four crucial elements that identify the growing Chinese mode of production: partial integration into the world capitalist economy; profit as the universal criterion for economic activity; commodification of labour-power; and the creation of a new bourgeoisie. Still, the developments are in the early stages and during such a rapid social restructuring and transformation the pictures are multifaceted and differentiated.

The justification of these different stages in China's development have changed markedly. What about the justification nowadays?

\section{Changing Conditions of Appropriation in China}

\section{The Role of the Party and the State}

A significant feature of the Chinese transition over the last decades has been the offensive initiative of the state. There has been no sign of state collapse. The economic reform has grown out of the central state plan..$^{5}$ As Maurice Meisner has put it, 'the coercion of the market is enforced by a repressive state apparatus, whose functioning includes the disciplining of the workforce and keeping social conflicts within bounds', which is the actual 'dictatorial and repressive character of the Chinese 
state'. ${ }^{6}$ On the other hand, there has been a rolling back of the state as government expenditure fell from 41 per cent of national income in 1978 to 23 per cent in 1989. The continued central role of the state, however, is due to the influence of a modernizing elite consisting of state bureaucrats, managers and technocrats of state enterprises, many of whom were already in leading positions before 1978. The PRC's development since 1978 has been a history of economic restructuring rather than a modernization, argues David S. G. Goodman.7 This could be related to the fact that the Chinese state has lacked institutionalization and therefore should be regarded as a political elite. ${ }^{8}$

In the case of China a centralized communist state has provided the framework for industrialization and today it is this same Communist Party apparatus that provides the incubator for the capitalist revolution. The new rich emerge from the state itself in a process that blurs notions of public and private, state and market. ${ }^{9}$

The Chinese bourgeoisie was eliminated by 1956 . Therefore a class of capitalist entrepreneurs had to be created to permit a market economy to function. The state became the creator more than the instrument of the bourgeoisie. The dependence of the state, on the other hand, became reinforced by the eagerness of the most successful private businessmen to join the Communist Party, where the principal qualifications for membership now appear to be wealth and loyalty to the communist regime. Students who graduate from Chinese universities are also often eager to join the Party. The combination of advanced education, still a very scarce resource in China, and Party membership, is an entrance ticket to prosperity for youngsters. Today the number of Party members is higher than ever and the role of the Party has changed fundamentally.

\section{Privatization}

State ownership has been the bedrock of the communist regime in China. Privatization has therefore been a search for compromises between what is politically tolerable and what is economically necessary. Instead of massive privatization, there have been proposals of measures transforming the state enterprises 
into share-holding companies. These measures include the share-holding being organized on a so-called co-operative basis; the progressive withdrawal of the state; establishing holding companies as subsidiaries of the central industrial ministries; and the introduction of public share companies run by local municipal authorities, etc. Locally the processes have gone further. Even foreign capital has taken over Chinese state enterprises. The 15th Party Congress decided on an ownership reform legalizing the above-mentioned measures. One major task is to transform the state enterprises from societal organizations into purely profit-making companies, thereby removing their character as socialist institutions. This represents a significant ideological break. In essence, the government's plan is gradually to divest itself of all but the 3,000 largest and most important state-owned enterprises. The smaller ones will be allowed to merge, go bankrupt, sell stakes to their employees, or, as is now increasingly common, be bought out by their management.

Who is likely to take advantage of these developments? Some of the agents of change are more likely than others to strengthen their power and economic situation. These are suggested to be the managers in co-operation with Party-state decisionmakers. Studies in Shenyang conclude that

The most notable element in the reform of state industry is the progressive increase in managers' independence. ... commercial enterprises are set up whose principal strength is to play on the duality of prices. The gongsi buys at the official price and sells at the market price: 'Profiting from this market on lack of goods, certain managers use their power in nearly all areas, from consumer goods to raw materials, from exporting rights to the trade in luxury cars. They operate both within and beyond China. All these people need in order to operate are name cards, a licence, a telephone and a bank account. In this way they make staggering profits. ${ }^{10}$

The participants in state business have acquired their 'own' businesses in many different ways. We can talk about a process of spontaneous privatization. Small shareholders and workers are largely excluded from this process. The reforms in owner- 
ship in Shanghai reveal that the Party has continued its control by personal arrangements that include assigning new titles to former bureaucrats who are then given a fresh opportunity in a corporate world. This lessens potential political resistance to any restructuring moves and allows the branch of the partystate to remain a major force in the governance of the new State Holding Corporations. ${ }^{11}$

\section{Clientelism}

While bonds of blood distinguished the interpersonal relations in feudal Europe, contract became the character of the relations between actors as markets developed. While familism was radically eroded by industrial capitalism in Europe, it has survived in China until recent time. The institution of guanxi in China is supposed to have been much stronger than European familism. Fei Xiaotong has proposed a specific Chinese mode of association, namely the 'differential mode of association', founded on the guanxi.12 The system survived Maoism, and some argue that guanxi even increased during the Cultural Revolution. Today there is a discussion on whether guanxi will give Chinese capitalism its distinctive stamp.

A distinction has been drawn between guanxi practice as a 'backdoor' system in conflict with the rational-legal system emerging at the state level (i.e. formal laws, policies and rational procedures) and guanxi more broadly conceived as a necessary part of the market reforms and business transactions in a market economy. Guanxi implies social relations, while guanxi practice implies the use of these social relationships to make exchanges, manufacture indebtedness, or accomplish tasks. ${ }^{13}$ While Mayfair Yang's argument is that there has been a growing importance of guanxi and guanxi practice in all types of commercial transactions during the economic transition in China, ${ }^{14}$ Guthrie questions such a conclusion. He bases his view on indepth interviews in the urban industrial economy. He gives three explanations of his empirical findings. First, China is in the process of constructing a rational-legal system at the state level and formal rational bureaucracies at the firm level, and large organizations are monitored by the state much more 
Torstein Hjellum

closely than are individual actors in the economy. Second, markets in China are becoming increasingly competitive, which means that there are very real economic incentives and constraints against favouring social ties over the economic imperatives of quality, price and the feasibility of a given project. In addition he argues that officials in China's transitional economy have no such control over the distribution of resources and products, and that an open market increasingly controls the flow of goods. Guthrie refers to the self-image of many Chinese managers who not only view guanxi as an important aspect of market economies, but who believe this to be true throughout the world rather than something particular to China.

Anyway, guanxi is now often associated with corruption and something criminal because it was regarded as such during the Mao period when egalitarianism and purism were official norms. David L. Wank states that

Patron-client ties are pervasive in the post-Mao economy between entrepreneurs operating firms and cadres staffing the state's administrative, distributive and production organs.. ${ }^{15}$

According to this author, the system is not of a transitory nature. It is not clear from Wank's discussion whether and to what degree the system he describes is peculiar to Chinese capitalism. Of course, in practical details, the system has its Chinese characteristics, however, it is unclear if it is designating a specific mode of capitalism.

Margaret Pearson concludes her study on the new business elite with the remark: 'The pervasiveness of clientelism suggests strongly that the new business elite does not represent an emerging civil society. ${ }^{16}$

There is no doubt that economic life is much more regulated by law today, compared with the situation 20 years ago. It is also relevant to argue that a legalistic culture runs much deeper than the simple construction of laws. However, it sounds a reasonable assumption that the growing economic structures comprising nationally and internationally operating businesses 
should converge with the structures of Western and globalizing capitalism.

\section{The Opening Up to the Outside World}

As the delinking strategy of Maoism was abandoned from the beginning of the 1970s, the Chinese economy has consequently been integrated, formally and in real terms, into world capitalist regimes. The Chinese state has to relate to institutions like IMF, the World Bank and WTO. When the currency, the yuan, is made fully convertible, the laws of a capitalist world market will work as strong determinants in the Chinese economy. Likewise, the daily operations by Chinese business on international markets and the joint ventures of Chinese and foreign capital, should change the conditions of appropriation and restructure the economic elites-what I now call the Chinese bourgeoisie-streamlining them to Western standards.

\section{From Ideology to Technocracy}

The Maoist idea that being red was more important than being expert, has been turned upside-down in the post-Mao era. The third echelon of party leadership, i.e. leaders recruited since the end of the 1980s, has produced few ideologists but an increasing number of men with higher and technocratic education. A technocratic mentality seems to have found its way into the leadership. ${ }^{17}$ However, Dengist slogans such as 'Somebody has to be rich first' lend legitimacy to capitalist modes of appropriation.

\section{The Composition of a New Chinese Bourgeoisie}

A capitalist class is composed by different sub-classes or segments defined by the various sources of their capital, the different roles in the economy's division of labour (industrial production, trade, finance, etc.) and the amount of capital owned or controlled by them. According to wealth, power and status the capitalists may be described as a hierarchy. A much debated theoretical problem is how to define the boundaries of 
classes. Another problem is the changing composition due to upward and downward mobility.

Sources of private capital accumulation, applied to the Chinese situation, can be categorized as follows: misappropriation of state assets or confiscation of former collectively owned capital; foreign capital, investment and loans, joint ventures, Chinese management of foreign capital; household savings (sometimes used compulsorily to rescue state enterprises); direct exploitation through production of surplus value; trade; privatization of state enterprises (direct or indirect); commercial farming and landholding based on management of formerly collectively owned land (contracts); illegal (if laws exist) operations (mafia capital); state-owned capital, etc. Each of these sources of capital accumulation constitutes disparate class segments consisting of socially disparate people according to their social origin or capital: former imperial business families; party/state bureaucrats (including the military) and their families (nepotism); managers of state enterprises; younger people with higher education; compradors; private entrepreneurs (families) in industry, trade, transport, etc.; and peasants. The disparate genesis of these class segments represents potential differences in interests and outlook, both among themselves, and compared with capitalist classes in other societies. Different concepts have been proposed to describe the specificities of Chinese capitalism: 'cadre capitalists', 'nomenclature capitalists' and 'bureaucrat capitalists'. Meisner uses the concept 'nouveaux riches-an assortment of private entrepreneurs, compradors, managers, technicians, small industrialists, and profiteering bureaucrats' and 'an upper bourgeoisie'18 and refers to an estimated 10 million millionaires (in Chinese yuan) currently in China.

A closer description of some of the potential important segments of a new bourgeoisie in China today include the following: 19

1. The rural petty bourgeoisie. This class became a result of the decollectivization of farming. It is a class made up of small landlords, commercial farmers, and small businessmen variously involved in commerce, in the operation of service companies, 
and in village and township industrial enterprises. Communist Party cadres not only served as midwives for the birth of the new class but also make up (along with their relatives and friends) a substantial portion of its membership. As has been the general rule in the history of the People's Republic, this was clearly a case where economic power flowed directly from the possession of political power. ${ }^{20}$

2. Technocrats: ${ }^{21}$ engineers, technicians, and high-level mechanics on the management level in formally state owned companies: 'Their relation to capital was not expressed in legalistic property terms - but, in fact, they controlled it exactly as if they owned it.'22 'The children of the pre-revolutionary bourgeoisie formed the core of this "new class" of technocrats, along with selected representatives of the old proletariat.'23

3. State and party high officials. These privileged groups of people formed social classes during the development of the People's Republic since 1949. Reproducing mechanisms were: nepotism; high education through elite schools; promotion through guanxi relations; arranged marriages. After the 14th Party Congress (1992) the Central Committee opened up for Party units and cadres to operate businesses. Earlier quite a number of officials formed quasi-governmental corporations that were in practice no different from state companies. Many have now set up private companies and joint ventures and joined the ranks of the private businessmen. ${ }^{24}$

Some private capital is accumulated by misappropriation of state assets. Misappropriation includes the sale or concession of property for private use by the bureaucracy or the management, the theft of raw materials or machines, and an absence of records or undervaluations of the state property brought into joint enterprises with foreign companies. Misappropriation takes place on an enormous scale. ${ }^{25}$

4. Individual entrepreneur households. At the time of the 14th Party Congress, China boasted of more than 14 million 'individual entrepreneur households', which provided employment for some 23 million workers. These individual businesses are controlled by bureaucrats and the Party through 'Self-employed Labourers Associations' and they constitute an important mate- 
Torstein Hjellum

rial basis for bureaucrats through taxation. In the absence of formal institutionalization, the relations between the individual businesses and the local authorities (as tax bureaux) represent an area prone to power abuse and corruption. ${ }^{26}$ The 'individual entrepreneur households' and 'bazaar'-activities may escalate into larger-scale capital accumulation through financial transactions, Triad connections, mafia-like activities etc., as economic life gets out of political control.

5. Private company owners. By 1992 there were 120,000 fully fledged private companies, which had more than 2 million employees. More than 11,000 of these private concerns were companies with limited liabilities, a jump of 72 per cent over the 1991 figure. The fixed assets of these private business units were mushrooming: the largest one had assets of RMB 45 million. ${ }^{27}$ On this level of private activities we may talk about developed capitalism and real capitalists. The 14th Party Congress rescinded an order given in late 1989 which forbade individual and private entrepreneurs from becoming $\mathrm{CCP}$ members. By the end of 1992, there were nearly 2 million CCP affiliates who were either the bosses or higher employees of private enterprises. ${ }^{28}$ In 1982 the right to inherit private property was written into the Constitution.

6. Compradors. These were in the beginning of the reform era offspring of high-level cadres who thanks to their influence in the bureaucracy, were able to arrange deals between foreign companies and state trading organizations. As Meisner comments, 'The lucrative "commissions" they earned in this compradore role was the first important source of substantial capital accumulation by private individuals in the history of the People's Republic. ${ }^{29}$ The Chinese have also become agents of foreign capital investors with more or less autonomy to make decisions on behalf of the owners. The role as compradors has traditions that can be traced back to the first half of the 19th century in China.

According to Hong Kong Economic Journal there are 303,000 foreign-funded enterprises in mainland China:

China has become the largest direct foreign capital importer among developing countries and the second largest direct 
foreign capital importer in the world ... foreign capital has infiltrated each and every aspect of China's national economy and each and every region in China. ${ }^{30}$

7. The military, through the building up of a militaryindustrial complex in China ${ }^{31}$-from military industry to civilian production-form an important sector of the state economy. As a result of the reform measures of the 1980s and the rush for profits in the 1990s, significant portions of Chinese defence production capacity have diversified into civilian production. This has been a question of survival. Even if the money-making production operations have been officially banned, the state resources are limited and not sufficient to let the huge military sector keep going. A revival of military profitseeking activities is therefore likely. ${ }^{32}$ The PLA has also been the biggest political loser in the reform of the political system. It has lost its multifunctional role, being confined to a purely military one. On the other hand, the civilian political elites are dependent on the military for their future survival. In this context the question of a relative autonomy of a military elite, with professional military and profit-seeking interests, as a stratum of a new ruling class, is of critical importance. ${ }^{33}$

8. Overseas Chinese, through family or clan relations within China. The amount of capital invested by overseas Chinese (of which there are 55 million in East and South-East-Asia) is considerable.

\section{Reorganization and Restructuring of Ruling Elites and Classes}

The question of dominant and/or ruling class(es) contains several degrees of complexity. In a society where the economy is marked by a tendency to commodify everything, capitalist classes are dominating economically. That means also subordination of other classes, in other words 'the dull compulsion of economic relations'. This economic dominance is the main source-sometimes in indirect and complex ways-of a general social dominance; that is to say, the acquisition of social privi- 
Torstein Hjellum

leges and the permeation of social life and institutions with a capitalist ethos, or the values of the capitalist class. It is also the source of a cultural dominance through the legal institutions, the educational system and the mass media. But this general dominance is neither monolithic nor unchallenged. Social and cultural dominance does not flow automatically from economic power. Dominance needs to be maintained and assured by political power. The question is to what extent capitalists act as a collective actor. Collective actors are very complex entities. However, capitalists tend to operate more collectively than other classes. They are a minority with high degree of social and political interaction, through family connections, associations deriving from distinctive educational experience, interlocking directorates, business associations, pressure groups, and so on. On the other hand, actions may be confused and unsecured, and power is always limited.

The success in maintaining a dominant position may be measured by the effects of actions on the social structure and the reproduction of social relations. One important effect may be the reproduction or increase of inequalities in the distribution of wealth and income. Looking to Western industrialized societies, it seems clear, not least during the last decades, that the capitalist classes have been successful in this respect. From 1945 to the 1970 s a generally rising standard of living, brought about by rapid economic growth, full employment and a great expansion of social services, reinforced the dominance of capitalist classes. Conversely, their dominance and their capacity to rule are threatened by economic recession, growing inequality, mass unemployment, increasing poverty and widening social divisions.

What then are the attributes of the rising capitalist classes-of the new Chinese bourgeoisie-in building a position of class dominance?

\section{Relations to the State}

Because the classes aspiring to be a part of a Chinese bourgeoisie derive directly from Party- and state-led economic reform policies, they are thought to be backed by state and Party 
power. The economic and political elites are possibly more intertwined in China than in most other societies. Meisner's argument is that 'the members of China's new bourgeoisie emerge more as agents of the state than as potential antagonists, providing the bureaucracy with an economic base and the communist state with a new social base.'34 A survey on investors in private business from 1993 revealed that:

A considerable portion ( $1 / 3$ of the urban sub-group, and $1 / 5$ of the rural sub-group) of these entrepreneurs were cadres or skilled technical personnel, a group that ranked among the highest both in income and prestige within the old system of a planned economy ... Generally speaking, cadres-half government functionaries and half business managers-were at the core of the social networks of entrepreneurs in both cities and towns and rural areas. ... a good relationship with the government was an important prerequisite for having a satisfying income. ${ }^{35}$

However, the development has also demonstrated a significant upward mobility. Many former workers and peasants have been members of the new economic elites. The party delivers ideological legitimacy for the reforms and thus secures a heavy cultural influence among subordinate people. The very strong economic growth in BNP has not only favoured the capitalists, but also secured a substantial growth in living conditions of rapidly growing middle classes and more privileged workers of all kinds. As long as this development continues, the regime will have a basis of legitimacy. Another asset of the growing new upper classes is the integration of the Chinese economy in global capitalism. Huge international business corporations have vested interests in a socially stabilized China and will, if confronted with a huge and complex China in disarray, have powerful means to exert influence. Serious international economic recessions may however weaken these avenues of influence.

The concept of 'civil society' has been developed in the West to refer to state-autonomous social formations arising as significant aspects of liberal capitalism. The question is whether this dualism between state and society is a relevant concept of 
Torstein Hjellum

understanding the Dengist era in China.36 Does the restructuring of the ruling class necessitate the growth of a civil society among the new economic upper classes, or will the Party take care of such needs? ${ }^{37}$

There are several associations that are supposed to serve as conduits between the state and private enterprises. The most important among them seems to be the Self-Employed Labourers Association (SELA), which the government established for small-scale vendors and other small private business operators (getihu, up to seven employees; $1,800,000$ members in 1981, 21,500,000 in 1997); an association for somewhat larger proprietors, namely the Private Enterprises Association (siying, eight or more employed; 91,000 members in 1989, 430,000 in 1997); and one for owners of the biggest businesses, viz. the AllChina Federation of Industry \& Commerce (ACIFIC) $(340,000$ members in 1990, 1,020,000 in 1996); and China's Foreign Sector Business Association (CAEFI) (15,000 enterprises as members 1992). ${ }^{38}$ They are all supposed to serve as intermediaries between the state and different levels of the private sector. The two first mentioned are, according to Unger, overwhelmingly dominated by the bureau that runs them, while the Federation of Industry \& Commerce has been provided with sufficient 'space' for it to serve as a genuine conduit between the state and a reinvigorated big-business sector. Related to the subject of this article, the two last-mentioned associations are of primary interest. The two others do organize a petty bourgeoisie (or non-elite capitalists) of a very different kind. Even if these classes are important in the development of capitalism, they are however secondary in an analysis of economic elites, even if they occasionally may serve as a recruitment ground for a business upper class.

The question is whether associations like ACIFIC and CAEFI promote the interests of their members from a position of autonomy and whether they reflect the emergence of pluralism or civil society?

The All-China Federation of Industry \& Commerce was established in 1953 as the government's 'representative' organization for the pre-revolution capitalists. In 1979 Deng Xiaoping 
called in several former businessmen from prominent prerevolution families and requested them to assist in the organization's rejuvenation. ${ }^{39}$ They helped to secure the Federation financial independence. The Federation was initially associated with one of the so-called democratic parties, the China National Construction Association. By the end of 1992 the Federation had enrolled 620,000 members, some individual, some enterprises. It also became a member of the Chinese People's Political Consultative Conference. One of the Federation's prominent members, Rong Yiren, the scion of a major Shanghai capitalist dynasty, was elected in 1993 as a vice-president of the People's Republic of China.40 While state managers played a role in the beginning, the Federation has now become an association of state-independent private entrepreneurs with their own distinct interests.

While the official role of the Federation is to serve as a 'bridge' between state and private enterprises, there are several empirical indicators of an association moving from a 'state corporatist' role towards 'bottom-up' interest articulation. Likewise, the mushrooming of chambers of commerce also seems to provide semi-autonomous arenas for the articulation of private capitalist interests.

Pearson's analyses conclude that the state has tried to create channels of interaction between state and society 'to attempt to co-opt members of the business elite before they have a chance to engage in independent action on their own behalf'. 41

Even if there may be local variations, a general conclusion seems to be that among the three organizations SELA, the Private Enterprises Association and ACIFIC, only ACIFIC operates relatively independently from the state. It is possible that it aspires to represent a bottom-up initiated civil society. Paradoxically, the autonomy is required by involvement with the state and there are few signs of struggles for more independence. In a relatively insecure political situation, the private businesses are dependent on good relations with the state. ${ }^{42}$

The survey on investors in private business concludes 'that relationships among entrepreneurs themselves were insigni- 
Torstein Hjellum

ficant. The time is not yet ripe for them to form ideologies and organizations of their own.' 43

There seems to be a general tendency of nepotism in the recruitment of politicians in the post-Mao era. ${ }^{44}$ Sons and daughters of leading officials also play a role among the new business elite. Clientelism is also important in the functioning of the capitalist sector of the economy. Margaret Pearson concludes her study as follows:

[T] here is no compelling evidence that it [China's new business elite] has tried to influence government policy as an independent class, or that there is even sufficient cohesiveness for it to do so. Rather, its members collude extensively, and for well-defined purposes, with officials, especially at the local level, in order to create better chances for success. In other words, clientelism is the major currency of interaction. For private entrepreneurs, ties with local cadres are absolutely necessary to their success. ${ }^{45}$

A study of private business associations in China supports a hypothesis of integration between civil society and the state rather than competition and antagonism:

It seems that in the Chinese context a civil society may not develop separate from and in opposition to the state but rather in the niches and spaces that the state leaves open, and that it will grow in response to opportunities deliberately engineered or accidentally created by the state. And, in turn, such a civil society may make demands upon the state - not to undermine or weaken it but to constrain its behaviour in some circumstances and to endorse and support it in others. Thus under the new economic conditions in China, a civil society and the party-state may develop in a symbiotic tension involving mutual exploitation and support. ${ }^{46}$

Pearson summarizes three concepts or models which have stimulated interest among students who have focused on state-society relations in post-Mao China: totalitarianism, pluralism and clientelist/state corporatism. She argues that a combination of a clientelist and a state corporatist approach provides the best framework for explaining the pattern of state-society relations in the reform period. The pluralist or democratization model, including the emergence of civil 
society, she characterizes as 'merely wishful thinking ... Instead of civil society, the dominant pattern consists of a combination of socialist corporatism and clientelism. ${ }^{47}$

\section{A New Ruling ldeology?}

The new Chinese bourgeoisie still lacks a cohesive consciousness of their interests as a class. However, there exist ideological elements that justify its existence. One crucial idea is Deng Xiaoping's slogan that 'some must get rich first', implying that this is the precondition for the welfare of the whole Chinese nation. Capitalism became officially legitimated by the Party Congress in 1992, when the hybrid concept of 'socialist market economy' was officially sanctioned.

One scenario was put forward in 1990-91 by a group of Chinese communist 'princelings', including Chen Yuan, son of $\mathrm{CCP}$ patriarch Chen Yun, and Pan Yue, son-in-law of Politburo Standing Committee member Liu Huaqing. Conceding that traditional Marxist-Leninist doctrines had lost much of their power to explain contemporary events and inspire the Chinese masses, China needed to adopt a 'neo-conservative' political programme, emphasizing not violent class struggle but harmonious Confucian social order and discipline; not communist egalitarianism but bureaucratic capitalism; not proletarian internationalism but ardent Chinese patriotism. ${ }^{48}$ After the 15th Party Congress in 1997, China Perspectives summed up the situation as follows:

Behind a thin veneer of socialist ritual, the leadership is solely preoccupied with preserving a system that will ensure development, has the stability it requires and, at the same time, safeguards their privileges and status. This attitude, which one could label neo-conservative, leads them to reject any change to the political system. Yet at the same time, the new 'new class' knows full well that neither Marx nor Mao can be of any help in solving the economic problems which confront them. Jiang actually said as much in his report, quoting Deng: "The task which we are undertaking is a new one. Marx said nothing about it ... We have to find our way by trial and error.' In this respect the leadership is pragmatist through and through and quite willing to allow a certain kind 
Torstein Hjellum

of capitalism to develop in China as long as it remains the principal beneficiary. ${ }^{49}$

This means that the ideological heritage from the totalitarian state no longer represents a menace to the rising capitalist classes. However, it does not mean that these new classes are developing an ideological consciousness. At this stage of transition a pragmatic state utilitarianism should be what serves the new entrepreneurs best. Pearson also concludes her study along the same lines: '[T]he practical ideology of managers translates into a freedom not to be involved into politics and, concretely, an interest in avoiding politics so that they can focus on business. ${ }^{50}$

\section{Changing Class Relations}

As ownership of capital is privatized, in many different modes, the relations between managers and employees are expected to change. Studies of the development of the Chinese communist work unit, the danwei, may tell us something about such changes. One such study is Corinna-Barbara Francis' study of Haidian District's high-tech sector. ${ }^{51}$ The danweis are deeply embedded in social, governmental and cultural practices and norms and will not vanish easily under new economic and political conditions. The study concludes that

The lesser degree of state regulation over labour management in the non-state sector appeared to give managers in these firms even greater discretion and made the allocation of benefits in these firms even more hidden and nepotistic than in traditional work units. ... This delegation [of state] responsibility to the enterprise further helps explain the continuation of paternalistic approaches to personnel management in nonstate firms.

What the study illustrates is the emergence of new relations between managers, labour and the state. The state may have an incentive to delegate the former danwei's responsibility to the private managers, and enable them to do so, as an instrument of control and regulation of the growing workforce in the private sector. Reproduction of the old system may in return strengthen the managers' bargaining position and complicate 
the development of an autonomous labour organization. Perhaps here we can see the emergence of a specific Chinese way of managing the relation between capital and labour.

Other reports deny such a development. Anita Chan concludes her study of a factory producing sports footwear for the Western market by assessing that 'the myth of the Confucian ideal of worker-management harmony has been overtaken by a model straight out of the military textbooks. 52

\section{Conclusions}

The reform policies dramatically restructure the social system in China. New economic elites, based on a combination of state capital (expropriation of formerly collectively owned capital), state regulations and private capital, increasingly dependent on laws of capitalist markets, are taking the lead. Their raison d'être is a pragmatic revision of communist ideology and improved material living conditions of a majority of the Chinese people. The leading fractions of this elite seem still to be state cadres, with the Communist Party as their prime mover. Private entrepreneurs are for the time more or less a clientele of 'the nomenclature capitalists'; they do not yet form a social class and do not have a consistent ideology of their own. The private entrepreneurs could be defined as a social stratum rather than a mature, stable social class.

The need for stronger social, economic and political organizations may in the future be a response to growing oppositions and consciousness among 'new' classes of exploited salaried employees.

Torstein Hjellum is Associate Professor at the Department of Comparative Politics, University of Bergen, and has written books and articles on Chinese politics and he has been teaching Comparative Politics at Fudan University in Shanghai for a number of years. Contact adress: Department of Comparative Politics, University of Bergen, Christiesgate 15, N-5007 Bergen, Norway. Fax: (45) 55589 425. E-mail: torstein.hjellum@isp.uib.no. Hjellum 
Torstein Hjellum

\section{Notes}

1. The basic conditions of a capitalist economy are comprehensively stated by Max Weber (broadly consonant with Marx's conception and clearly derived from it): rational capital accounting as the norm for all large industrial undertakings, which involves the appropriation of all physical means of production as disposable property of autonomous private industrial enterprises; freedom of the market; rational technology and mechanization; calculable law; free labour (i.e. the existence of persons who are legally in the position and also economically compelled to sell their labour on the market without restriction), and finally the commercialization of economic life. Max Weber, General Economic History, London: Allen \& Unwin, 1927.

2. 'Chinese capitalism is unique because it is embedded both in Chinese culture and in political and institutional histories of several environments. These environments, such as Taiwan, Hong Kong and ASEAN, have induced different responses to the challenges of co-ordinating economic behaviour, but certain underlying universals remain. One of these universals is endemic mistrust and the response to it in specific trust-bonding which so pervades the economic system. Another is the retention of paternalism as the core legitimating principle underlying authority structures generally and business organizations in particular.' S. G. Redding, 'The Distinct Nature of Chinese Capitalism'. The Pacific Review, 9 (3) (1996): 439.

3. This concept is developed in Juan J. Linz and Alfred Stepan in Problems of Democratic Transition and Consolidation, Baltimore: The Johns Hopkins University Press, 1996. This sets out the following characteristics: 'Pluralism: Limited, but not responsible, social, economic, and institutional pluralism. Almost no political pluralism because party still formally has monopoly of power. May have "second economy", but state still the overwhelming presence. ... Ideology: Guiding ideology still officially exists and is part of the social reality. But weakened commitment to or faith in utopia. Shift of emphasis from ideology to programmatic consensus that presumably is based on rational decision-making and limited debate without too much reference to ideology ... Mobilization: Progressive loss of interest by leaders and non-leaders involved in organizing mobilization. Routine mobilization of population within state-sponsored organizations to achieve a minimum degree of conformity and compliance. Many "cadres" and "militants" are mere careerists and opportunists. Boredom, withdrawal, and ultimately privatization of population's values become an accepted fact ... Leadership: Growing emphasis by post-totalitarian political elite on personal security. Checks on top leadership via party structures, procedures, and "internal democracy". Top leaders are 
seldom charismatic. Recruitment to top leadership restricted to offi cial party but less dependent upon building a career within party's organization. Top leaders can come from party technocrats in state apparatus.'

4. Meisner argues that bureaucratic capitalism was restored by Deng Xiaoping's institutionalization of bureaucratic power and the introduction of a market economy. See M. Meisner, The Deng Xiaoping Era. An Inquiry into the Fate of Chinese Socialism 1978-1994. New York: Hill \& Wang, 1996.

5. This is the central thesis of Barry Naughton, Growing Out of the Plan: Chinese Economic Reform 1978-1993. Cambridge: Cambridge University Press, 1995.

6. Meisner, op. cit.

7. David S. G. Goodman, 'The Party-state, Capitalist Revolution and New Entrepreneurs'.In R. Robison and D. S. G. Goodman (eds), The New Rich in Asia. London and New York: Routledge, 1996.

8. 'Two contradictory aspects of Chinese politics-the powerful party-state and the utter lack of institutionalization-lead one to view the Chinese state as a political elite rather than as institutionalized sets of offices whose incumbents are empowered to exercise the state's authority.' Hong Yung Lee, 'From Revolutionary Cadres to Bureaucratic Technocrats'. In Brantly Womack (ed.), Contemporary Chinese Politics in Historical Perspective. Cambridge: Cambridge University Press, 1991, p. 180.

9. Richard Robison and Davis S. G. Goodman (eds), The New Rich in Asia. London and New York: Routledge, 1996, p. 15.

10. Antoine Kernen, 'State Enterprises in Shenyang'. China Perspectives 14 (1997): 27.

11. Christopher A. McNally, 'Shanghai's Way Forward. A Prelude to China's Next Stage of Enterprise Reforms'. China Perspectives 14 (1997).

12. The concept is used in Fei Hsiao-t'ung, From the Soil. Foundations of Chinese Society. Berkeley: University of California Press, 1992.

13. Douglas Guthrie, 'The Declining Significance of Guanxi in China's Economic Transition'. China Quarterly 154 (1998).

14. Mayfair Yang, Gifts, Favors, and Banquets, The Art of Social Relationships in China. Ithaca, NY: Cornell University Press, 1994.

15. David L. Wank, 'The Institutional Process of Market Clientelism: Guanxi and Private Business in a South China City'. China Quarterly 147, (1996): 820.

16. Margaret M. Pearson, China's New Business Elite. Berkeley: University of California Press,1997, p.101.

17. Cf Jan Ivar Longva, From Guerrilla Fighters to Engineers - Towards a Technocratic Leadership in China? Thesis, Department of Comparative Politics, University of Bergen, 1997.

18. Maurice Meisner, 'The Other China'. Current History (September 1997): 264. 
Torstein Hjellum

19. How far one should go in specifying segments of the capitalist class is a question of intention. In the Japanese case, which has many similarities with the Chinese case (viz. the central role of the state in the genesis of capitalism), one can distinguish three main groups: (1) individual entrepreneurs, (2) directors and managers of corporations, and (3) government officials. Cf. Koji Morioka, 'Japan'. In T. Bottomore and R. J. Brym (eds), The Capitalist Class: an International Study. New York: Harvester Wheatsheaf, 1987.

20. Meisner 1996, p. 317.

21. Longva, op. cit.; Hong Yung Lee, 'China's New Bureaucracy'. In Arthur L. Rosenbaum (ed.), State \& Society in China. The Consequences of Reform. Boulder, CO: Westview Press, 1992, pp. 56-60.

22. Lynn T. White III, 'Bourgeois Radicalism in the "New Class" of Shanghai, 1949-1969', in Watson 1984, Class and Social Stratification in Post-Revolution China, Cambridge: Cambridge University Press, p. 163.

23. Watson, op. cit., p. 10.

24. 'In mid-1992, Bo Xicheng, the son of venerated elder Bo yibo ... resigned from his post as of head of the Beijing Tourism Bureau to start a semiprivate hotel management company in the capital. "In reform, someone has to take the lead," said the 41-year-old "princeling". "We must learn to be independent and to earn our own bread"'. China Review 1993. The Chinese University Press, Hong Kong 1993: 2.21.

25. Cf. Jean-François Huchet, 'The 15th Congress and the Reform of Ownership', China Perspectives 14 (1997), and Kernen, op. cit.

26. An interesting case-study of this relationship is given by Ole Bruun, Business and Bureaucracy in a Chinese City, Berkeley: University of California, Institute of East Asian Studies, 1993, esp. ch. 5: "The Continuity of Bureaucratic Power'.

27. China Review 1993 according to 'New China News Agency', 29 October 1992.

28. China Review 1993, The Chinese University Press, Hong Kong 1993: 2.21.

29. Meisner 1996, p. 319.

30. Hong Kong Economic Journal 4 May 1998.

31. See Mel Gurtov, 'Swords into Market Shares: China's Conversion of Military Industry to Civilian Production'. China Quarterly, 134 (1993).

32. Cf. John Frankenstein and Bates Gill, 'Current and Future Challenges Facing Chinese Defence Industries' and Artur S. Ding, 'China's Defence Finance: Content, Process and Administration'. The China Quarterly 146 (1996).

33. 'Out of sheer political necessity, Jiang Zemin has been a good friend to the Chinese army. During his tenure as chairman of the Central Military Commission, he has repeatedly supported increased defense spending; promoted the modernizartion and professionalization of the armed 
forces; permitted the PLA to engage in free-wheeling, for-profit commercial enterprise; and personally given promotions to dozens of his generals.' Richard Baum, 'The Fifteenth National Party Congress: Jiang Takes Command?' The China Quarterly 153 (1998): 154.

34. Meisner 1996, p. 339.

35. The Project Group for Research on Private Entrepreneurs in Contemporary China, Social Sciences in China 16.2 (1995): 62.

36. Cf. Timothy Brook and B. Michael Frolic (eds), Civil Society in China. London: M.E. Sharpe; 1997 and Heath B. Chamberlain, 'Civil Society with Chinese Characteristics?'. The China Journal 39 (1998).

37. Gordon White, Jude Howell and Shang Xiaoyuan, In Search of Civil Society: Market Reform and Social Change in Contemporary China. Oxford: Clarendon Press, 1996.

38. They are described and analysed by Jonathan Unger, "Bridges": Private Business, the Chinese Government and the Rise of New Associations'. China Quarterly 147 (1996) and Margaret M. Pearson, China's New Business Elite. Berkeley: University of California Press, 1997.

39. Cf. Unger, op. cit.

40. His son, Rong Zhijian, is reported to have private assets of 3.5 billion yuan. Caifu (China Rich) 8 (1996).

41. Pearson, op. cit., p. 141.

42. This is according to a review of literature and information collected by Miriam Kvanvik, Kina og det sivile samfunn [China and the Civil Society]. Master's thesis, Department of Political Science, University of Oslo 1998.

43. Ibid., p. 63.

44. Longva, op. cit. p. 102.

45. Pearson op. cit., p. 115.

46. Christopher Earle Nevitt, 'Private Associations in China: Evidence of Civil Society or Local State Power'. The China Journal 36 (1996): 43.

47. Pearson, op. cit., p. 141.

48. Richard Baum, op. cit., p. 154.

49. Michael Bonnin, 'The 15th Congress: Reforms In, Politics Out.' China Perspectives. 14 (1997): 7.

50. Pearson, op. cit., p.140.

51. Corinna-Barbara Francis, 'Reproduction of Danwei Institutional Features in the Context of China's Market Economy: The Case of Haidian District's High-Tech Sector'. The China Quarterly 147 (1996).

52. Anita Chan, 'Regimented Workers in China's Free Labour Market'. China Perspectives 9 (1997): 12. 